\title{
DISKRESI DALAM PENETAPAN UPAH MINIMUM OLEH GUBERNUR
}

\author{
Setyo Pamungkas \\ Pegawai Negeri Sipil pada Dinas Ketenagakerjaan, Sosial dan Transmigrasi \\ Pemerintah Kota Salatiga \\ Korespondensi: setyopamungkas@gmail.com
}

\begin{abstract}
Abstrak
Upah minimum bertujuan untuk memberikan perlindungan bagi pekerja dari upah yang terlalu rendah. Upah minimum mendorong terwujudnya keadilan bagi pekerja-pengusaha, dan pemenuhan kebutuhan hidup minimal bagi semua yang bekerja dan yang memerlukan perlindungan. Upah minimum ditetapkan oleh Gubernur. Gubernur dalam menetapkan upah minimum dapat menggunakan pertimbangannya sendiri tentang upah yang layak, karena pekerja/buruh tidak boleh dibayar di bawah nilai kebutuhan hidup layak dan perlindungan sosialnya. Gubernur juga berperan penting dalam mengembangkan kebijakan upah minimum. Jadi, Gubernur dapat melakukan diskresi untuk memastikan bahwa keadilan sosial dapat dicapai melalui kebijakan upah minimum. Akan tetapi, diskresi tersebut harus benar-benar memastikan negara memberikan perlindungan yang sama bagi pekerja dan pengusaha.
\end{abstract}

Kata-kata Kunci: Upah Minimum; Diskresi; Perlindungan Upah.

\begin{abstract}
The establishment of minimum wage standard aims to provide protection for workers from wages that are too low. The minimum wage standard encourage the achievement of justice for workers as well as employers, and the minimum subsistence for all workers whose living standard needs to be protected. The minimum wage is established by the provincial governor, who may at his/her discretion establish the minimum wage at the rate she/he deemed decent, since for workers / laborers should not be paid below the needs of decent living and of social protection. The governor also plays an important role in developing policies on minimum wages. Therefore, the governor may excercise his/her discretion to ensure that social justice can be achieved through the minimum wage policy. However, such discretion must assure that the state provides equal protection for workers and employers.
\end{abstract}

Key Words: Minimum Wage; Discretion; Protection of Wages. 


\section{PENDAHULUAN}

Penetapan upah minimum adalah perintah undang-undang, yang dimaksudkan agar pekerja/buruh terhindar dari kesewenang-wenangan pengusaha dalam hal pembayaran upah, atau hanya menjadi tujuan bisnis semata. Bahwa konsep "minimum” sendiri memiliki kandungan arti habis dibelanjakan dalam tempo satu bulan. Upah yang diberikan kepada karyawan didasarkan pada perhitungan tentang kebutuhan minimum karyawan per bulan. Kebutuhan minimum di sini selalu berhubungan dengan kebutuhan primer (sandang, pangan, papan). Istilah "minimum" tersebut berarti hanya cukup untuk makan-minum, sewa rumah atau kontrakan, dan beli pakaian dalam satu bulan. ${ }^{1}$

Negara memandang perlu turut ambil bagian untuk memberikan kepastian terhadap jaminan perlindungan atas upah yang layak bagi pekerja. Upah menghubungkan antara kepentingan ekonomis pengusaha, kesejahteraan pekerja/buruh, dan upaya intervensi negara dalam hubungan kerja. Paradigma mengenai peran dan fungsi negara di bidang ketenagakerjaan yakni konsepsi welfare state diajukan untuk terus diperkuat. ${ }^{2}$ Gema kesejahteraan di bidang ketenagakerjaan terus dijaga adalah demi mem- berikan jaminan hak atas pekerjaan dan penghidupan yang layak bagi semua warga negara Indonesia, sebagaimana diatur dalam Pasal 27 ayat (2) Undang-Undang Dasar Negara Republik Indonesia Tahun 1945 (UUD 1945). Tujuan bernegara (staatside) secara tegas dan jelas di dalam Pembukaan UUD 1945, yakni "memajukan kesejahteraan umum" untuk mewujudkan "keadilan sosial bagi seluruh rakyat Indonesia". Tujuan ini menjadi landasan filosofis bagi penyelenggara negara untuk berusaha mewujudkannya.

Sebagai contoh, Gubernur Jawa Tengah pada tahun 2015 menerbitkan Keputusan Gubernur Jawa Tengah Nomor 560/66 Tahun 2015 tentang Upah Minimum pada 35 (Tigapuluh Lima) Kabupaten/Kota di Provinsi Jawa Tengah. Dalam keputusannya, Gubernur Jawa Tengah menetapkan upah minimum tersebut, ada 16 Kabupaten/Kota yang Upah Minimum Kabupaten/Kota (UMK) setara atau lebih dari nilai Kebutuhan Hidup Layak (KHL). Sedangkan sisanya, yakni 19 Kabupaten/Kota yang nilai UMK-nya kurang dari nilai KHL. Padahal secara filosofis, upah minimum harus mampu mencukupi nilai kebutuhan dasar bagi pekerja/buruh. Keputusan Gubernur tersebut menimbulkan pertanyaan apakah di dalam keputusan tersebut

L. Sinuor Yosephus, Etika Bisnis: Pendekatan Filsafat Moal terhadap Perilaku Pebisnis Kontemporer (Yayasan Pustaka Obor Indonesia 2010) 71.

Welfare state atau negara kesejahteraan, merupakan suatu tipe negara dalam konsep ketatanegaraan yang menitikberatkan pada pemerataan kesejahteraan dalam kehidupan rakyat, sehingga negara dituntut untuk berperan aktif dalam penciptaan kesejahteraan. Lihat Mirza Nasution, Politik Hukum dalam Sistem Ketatanegaraan Indonesia (Penerbit Puspantara 2005) 99-100. 
mengindikasikan adanya tindakan diskresi pejabat administrasi negara, dan apa alasan mendasar dilakukannya.

Penetapan dengan upah minimum dimaksudkan untuk melaksanakan fungsi mensejahterakan rakyat, yang dasar atau kewenangannya, diatur dan bersumber pada peraturan perundangundangan. Oleh karena negara Indonesia adalah negara hukum, maka peraturan perundang-undangan dapat bersifat mengikat dan bebas. Konsekuensi dari pelaksanaan asas negara kesejahteraan atau welfare state adalah intervensi pemerintah yang cukup luas terhadap aspek kehidupan bermasyarakat serta digunakannya asas diskresi. Dilema yang muncul adalah bahwa konsekuensi tersebut tidak dilaksanakan, maka fungsi administrasi akan terhambat yang berarti akan menghambat terwujudnya kesejahteraan dalam kehidupan masyarakat. ${ }^{3}$ Sama halnya di bidang ketenagakerjaan, maka fungsi dan peran negara adalah untuk mendorong tercapainya keadilan sosial di bidang ketenagakerjaan, khususnya upah yang layak. Sekalipun kemudian, hubungan kerja diawali dengan adanya perjanjian kerja antara pekerja dengan pengusaha, memiliki unsur perintah, upah, dan pekerjaan.
Upah menjadi salah satu unsur mutlak dalam hubungan kerja, menjadi pertanda bahwa pekerja memiliki hak atas imbal kerjanya, yang pantas dan layak untuk memenuhi kebutuhan hidupnya.

Kebijakan pengupahan oleh pemerintah diadakan untuk mewujudkan penghasilan yang memenuhi penghidupan yang layak bagi kemanusiaan, yang berarti menjadi wujud upaya perlindungan negara terhadap pekerja/ buruh. Penetapan upah minimum, didasarkan pada kebutuhan hidup layak dan memperhatikan produktivitas dan pertumbuhan ekonomi. ${ }^{4}$ Kebijakan ini nyata dan aktual dibuat dalam keputusan Gubernur sebagai satu-satunya pejabat administratif negara yang dapat mengeluarkan ketetapan tentang besarnya upah minimum (baik sektoral, provinsi dan kabupaten/kota). Hanya saja, di kalangan masyarakat pekerja/buruh dan pengusaha, upah minimum yang ditetapkan cenderung menimbulkan kegaduhan sosial dan menjadi sumber perdebatan politik. ${ }^{5}$ Gubernur juga kemudian menjadi sasaran kemarahan masyarakat pekerja/buruh dan kalangan pengusaha. Penetapan upah minimum, menjadi kebijakan pada ranah administrasi provinsi, yang menyesuaikan dengan

Ibid.

Lihat Pasal 88 Undang-Undang No. 13 Tahun 2003 tentang Ketenagakerjaan.

Upah minimum merupakan sumber perdebatan politik, dimana para pendukung upah minimum yang lebih tinggi memandangnya sebagai sarana meningkatkan pendapatan pekerja miskin. Upah minimum tentu saja hanya memberikan standar kehidupan yang lebih kecil. Meski para pendukung upah minimum seringkali mengakui bahwa kebijakan itu akan menyebabkan pengangguran bagi sebagian pekerja, namun setidaknya pengorbanan itu setimpal untuk mengentaskan kelompok masyarakat lainnya. Di lain pihak, ada pihak penentang upah minimum ditetapkan makin tinggi, karena hal itu bukan cara terbaik untuk membantu orang-orang miskin. Upah minimum tidak tepat sasaran, karena diterima bukan oleh sebagian besar pekerja yang merupakan kepala keluarga yang harus bekerja untuk menghidupi keluarganya. Lihat N. Gregory Mankiw, Makroekonomi (Penerbit Erlangga 2006) 162. 
potensi KHL masing-masing daerah Kabupaten/kota. Normanya sudah menyatakan bahwa upah minimum merupakan upah bulanan terendah yang ditetapkan pemerintah (Gubernur) sebagai jaring pengaman ${ }^{6}$, yang didasarkan pada nilai KHL. Akan tetapi, dalam hal penetapan upah minimum misalnya, pemerintah ternyata masih tetap mungkin menetapkan upah minimum yang nilainya ada di bawah standar nilai KHL. Padahal, nilai KHL disusun dengan melibatkan pekerja/ buruh dan pengusaha, untuk mencari kebenaran akan seberapa besar kebutuhan pekerja/buruh yang diformulakan dalam bentuk rupiah.

Gubernur Jawa Tengah pada tahun 2015 misalnya, menetapkan upah minimum pada 35 Kabupaten/ Kota (UMK) untuk tahun 2016, dimana sekitar 40\% dari 35 Kabupaten/Kota, upah minimum yang ditetapkan, nilainya di bawah nilai KHL. Gubernur memang berwenang untuk menetapkan upah minimum, namun adalah kewajiban Gubernur juga untuk memperhatikan saran dan pertimbangan serta rekomendasi dari pihak lain, yakni Dewan Pengupahan. Menetapkan upah minimum tidak serta merta sebesar atau setara dengan nilai KHL yang menjadi dasar penentuan besar upah (serta mempertimbangkan produktivitas dan pertumbuhan ekonomi).

Pertanyaan yang timbul dalam keadaan ini adalah pertimbangan seperti apa yang kemudian menyebabkan Gubernur menetapkan upah minimum di bawah nilai KHL dan apakah kebijakan yang demikian merupakan salah satu bentuk diskresi Gubernur di bidang pengupahan? Perlu dicermati dan ditelaah bahwa upah minimum harus mencerminkan kelayakan bagi penghidupan pekerja/buruh, namun ternyata tindakan administrator negara berbeda. Bila Gubernur menetapkan upah minimum di bawah nilai KHL, pertimbangan dan tujuan apa yang hendak dicapai. Sebagai produk administratif, upah minimum seyogianya mempertemukan kepentingan ekonomi dalam bisnis dengan jaminan akan perlindungan kesejahteraan bagi pekerja/buruh dan keluarganya.

\section{PEMBAHASAN}

\section{Diskresi dan Upah Minimum}

Diskresi bagian dari mekanisme di dalam penyelenggaraan pemerintahan, yang mendukung pelayanan birokrasi, baik secara internal organisasi maupun ekstra-organisasi. Penyelenggara pemerintahan diberikan kewenangan ini, demi inovasi dan tanggap terhadap perubahan. Diskresi dimengerti sebagai kebebasan seorang pejabat mengambil keputusan dalam setiap situasi yang dihadapi menurut pendapatnya sendiri. ${ }^{7}$ Kebebasan ini mendorong pejabat untuk dapat lebih kreatif memberikan respon terhadap perkembangan situasi dalam rangka

\footnotetext{
$6 \quad$ Lihat Pasal 1 angka 1 Peraturan Menteri Tenaga Kerja dan Transmigrasi Nomor 7 Tahun 2013 tentang Upah Minimum.

J.C.T. Simorangkir, dkk., Kamus Hukum (Sinar Grafika 2008) 38.
} 
penyelenggaraan pemerintahan. Dua bentuk diskresi: (a) diskresi bebas, di mana undang-undang hanya menetapkan batas-batas dan administrasi negara bebas mengambil keputusan apa saja, sepanjang tidak melampaui atau melanggar batas-batas tersebut; dan (b) diskresi terikat, di mana undangundang menetapkan beberapa alternatif keputusan dan administrasi negara bebas memilih salah satu alternatif keputusan yang sudah disediakan oleh undang-undang. ${ }^{8}$ Patut disimak bagaimana pengampu kewenangan diskresi, yakni pejabat administrasi negara, mampu menerjemahkan diskresi dalam bentuk putusan/ketetapan yang bebas, namun dalam ruang kebijakan tanpa melukai undang-undang.

Diskresi dalam arti freies ermessen didefinisikan sebagai kebebasan untuk bertindak atas inisiatif sendiri, akan tetapi pelaksanaan diskresi haruslah tindakan-tindakan administrasi negara sesuai dengan hukum, sebagaimana telah ditetapkan dalam kerangka negara hukum. Freies ermessen atau dalam istilah discretionary power adalah kewenangan administrasi negara untuk turut campur dalam kegiatan sosial guna melaksanakan tugas-tugas mewujudkan kepentingan umum dan kesejahteraan sosial atau warga negaranya. ${ }^{9}$ Diskresi ini kemudian mendasarkan kepentingannya pada arah dan tujuan kesejahteraan, yang menjadi capaian akhir. Kebebasan untuk membuat terobosan di dalam penyelenggaraan pemerintahan, demi tujuan kesejahteraan dapat terhubung dengan tujuan negara kesejahteraan (welfare state). Dengan demikian diskresi dianggap sebagai salah satu sarana yang memberikan ruang bergerak bagi pejabat atau badan-badan administrasi negara untuk melakukan tindakan tanpa harus terikat sepenuhnya pada undang-undang, atau tindakan yang dilakukan dengan mengutamakan pencapaian tujuan (doelmatigheid) daripada sesuai dengan hukum yang berlaku (rechtmatigheid). ${ }^{10}$

Diskresi yang bebas ditekankan untuk tidak dilaksanakan sebebasbebasnya. Pemerintah sendiri dalam mengupayakan pelayanan kepada masyarakat diperhadapkan pada kondisi yang berubah-rubah, sehingga perlu adaptable. Dalam melaksanakan tugas, pemerintah tidak hanya melaksanakan undang-undang saja, tapi juga melakukan perbuatan-perbuatan atau tindakan-tindakan yang belum diatur secara tegas oleh undang-undang. ${ }^{11}$ Koridor hukum menempatkan pemerintah untuk tidak secara tiba-tiba memperlakukan diskresi sebagai mekanisme yang dapat dipergunakan untuk menghadapi perubahan, tanpa memiliki pertimbangan yang rasional.

\footnotetext{
Julista Mustamu, Diskresi \& Tanggungjawab Administrasi Pemerintah (2011) 17 Jurnal Sasi 1, 3. Sjachran Basah, Eksistensi dan Tolok Ukur Peradilan Administrasi Negara di Indonesia (Penerbit Alumni 1997) 3. Lihat pula Ridwan H.R., Hukum Administrasi Negara (Rajawali Press 2008) 51. Ridwan H.R., Ibid. 80-81.

11 Philipus M. Hadjon, Pengantar Hukum Administrasi Indonesia (Gajah Mada University Press 2001) 270-278.
} 
Sejak hukum itu berubah dari substansi keadilan dan hidup berkeadilan menjadi teks, skema, kebahasaan, pelakunya berhadapan dengan substansi pengganti (surrogate), bukan lagi barang asli. Di sini tidak lagi dibicarakan tentang 'hukum sebenarnya', melainkan 'mayat-mayat hukum'. Pada waktu konsep berhukum berubah menjadi berhukum menjadi teks, maka ada satu lorong yang menjadi tertutup atau setidaknya menyempit, yaitu berhukum dengan akal-sehat (fairness, reasonableness, common sense). Berhukum yang berdasar teks memiliki kecenderungan kuat untuk berhukum secara kaku dan regimentatif. Dengan cara demikian, maka akan bersifat eksesif dan menimbulkan berbagai persoalan besar, khususnya dalam hubungan dengan pencapaian keadilan. ${ }^{12}$

Pasal 89 UU No. 13 Tahun 2004 mengatur bahwa penetapan upah minimum diarahkan untuk pencapaian kebutuhan hidup layak (ditetapkan Menteri yang membidangi ketenagakerjaan), serta harus mendapatkan rekomendasi dari Dewan Pengupahan. Kebijakan upah minimum dengan demikian harus melihat pada: (a) seberapa besar upaya pencapaian kebutuhan hidup layak, dan (b) rekomendasi Dewan Pengupahan. Gubernur memiliki kewajiban (atau kewenangan) untuk menetapkan upah minimum. Sehingga secara normatif ada kewenangan yang melekat sebagai pejabat administrasi negara untuk menetap- kan besarnya upah minimum. Kewenangan ini dapat disebut sebagai kekuasaan Badan dan/atau Pejabat Pemerintahan atau penyelenggara negara lainnya untuk bertindak dalam ranah hukum publik, sebagaimana dinyatakan dalam Pasal 1 Angka 6 Undang-Undang No. 30 Tahun 2014 tentang Administrasi Pemerintahan. Pejabat pemerintahan merupakan Badan dan/atau Pejabat Pemerintahan adalah unsur yang melaksanakan Fungsi Pemerintahan, baik di lingkungan pemerintah maupun penyelenggara negara lainnya (Pasal 1 angka 3 UU No. 30 Tahun 2014).

Pejabat ini memiliki suatu hak diskresi dalam mengambil keputusan dan/atau tindakan, yang sesuai dengan tujuan-tujuannya yang penting (Pasal 6 ayat (1) dan (2) UU No. 30 Tahun 2014). Diskresi dapat dilakukan oleh penyelenggara negara. Penyelenggara Negara menurut Pasal 1 angka 1 UndangUndang Nomor 28 Tahun 1999 tentang Penyelenggara Negara yang Bersih dan Bebas dari Korupsi, Kolusi, dan Nepotisme adalah pejabat negara yang menjalankan fungsi eksekutif, legislatif, atau yudikatif dan pejabat lain yang fungsi dan tugas pokoknya berkaitan dengan penyelenggaraan negara sesuai dengan ketentuan peraturan perundang-undangan yang berlaku.

Diatur dalam Pasal 1 angka 9, UU No. 30 Tahun 2014, diskresi dinyatakan sebagai Keputusan dan/atau Tindakan yang ditetapkan dan/atau

12 Satjipto Rahardjo, Hukum dan Perilaku: Hidup Baik adalah Dasar Hukum yang Baik (Penerbit Buku Kompas 2009) 14. 
dilakukan oleh Pejabat Pemerintahan untuk mengatasi persoalan konkret yang dihadapi dalam penyelenggaraan pemerintahan dalam hal peraturan perundang-undangan yang memberikan pilihan, tidak mengatur, tidak lengkap atau tidak jelas, dan/atau adanya stagnasi pemerintahan. Suatu diskresi menurut undang-undang ini hanya dapat dikeluarkan apabila tujuan penerbitan diskresi tersebut adalah: (i) untuk melancarkan penyelenggaraan pemerintahan; (ii) untuk mengisi kekosongan hukum; (iii) demi memberikan kepastian hukum; dan (iv) mengatasi stagnasi pemerintahan dalam keadaan tertentu guna kemanfaatan dan kepentingan umum.

Diskresi merupakan kewenangan yang penting bagi upaya peningkatan kapasitas melakukan perubahan. Akan tetapi, kewenangan aparatur untuk mengambil diskresi perlu diatur secara jelas. Kebutuhan pengaturan ini berkaitan dengan adanya peluang atau kesempatan untuk melakukan inovasi yang dapat menjadi terobosan baru bagi aparatur dan satuan birokrasi publik. Ketentuan untuk melakukan inovasi, prosedur, persyaratan, pendokumentasian dari kegiatan inovasi, dan pembelajaran dari setiap inovasi yang dilakukan perlu dibuat. Kewenangan untuk melakukan diskresi bilamana dapat dibuat, dapat menjadi basis legal bagi aparatur dan birokrasi publik untuk melakukan inovasi dalam rangka merespons kepentingan publik, kapasitas individual aparatur dan institusi birokrasi untuk melakukan perubahan akan semakin kuat. ${ }^{13}$

Diskresi atau ruang gerak bagi individu pelaksana di lapangan untuk memilih tindakan sendiri yang otonom dalam batas wewenangnya apabila menghadapi situasi khusus ketika kebijakan tidak mengatur atau mengatur berbeda dengan kondisi lapangan. Diskresi adalah kehormatan fungsional dari para pelaksana implementasi kebijakan, dikarenakan kebijakan adalah mati dan kehidupan masyarakat adalah hidup. Maka dalam pelaksanan kebijakan, pada tingkatan tertentu selalu diperlukan penyesuaian kebijakan dengan implementasi. Untuk itu, pelaksana kebijakan perlu diberi ruang gerak untuk melakukan adaptasi tersebut. Akan tetapi, diskresi harus diatur, dengan kata lain ada panduan diskresi akan membantu pelaksana untuk menyesuaikan diri apabila ada kasus-kasus yang bersifat khusus yang dihadapi ketika melakukan implementasi kebijakan. ${ }^{14}$ Menetapkan upah minimum merupakan kewenangan yang dimiliki Gubernur, yang melekat pula dalam kewenangan tersebut untuk melakukan diskresi. Oleh karena upah minimum adalah komoditas isu yang dapat mendorong gejolak sosial di kalangan masyarakat pe-

\footnotetext{
13 Agus Dwiyanto, Mengembalikan Kepercayaan Publik Melalui Reformasi Birokrasi (Gramedia Pustaka Utama 2011) 339-340.

14 Riant Nugroho Dwidjowijoto, Kebijakan Publik untuk Negara-Negara Berkembang (PT. Elex Media Komputindo 2006) 148.
} 
kerja/buruh dan pengusaha, maka intervensi pemerintah, diskresi atau tidak, secara materiil maupun secara formal, harus mampu mengantisipasi gejolak sosial tersebut.

Upah sendiri diartikan sebagai hak pekerja/buruh yang diterima dan dinyatakan dalam bentuk uang sebagai imbalan dari pengusaha atau pemberi kerja kepada pekerja/buruh yang ditetapkan dan dibayarkan menurut suatu perjanjian kerja, kesepakatan, atau peraturan perundang-undangan, termasuk tunjangan bagi pekerja/ buruh dan keluarganya atas suatu pekerjaan dan/atau jasa yang telah atau akan dilakukan. ${ }^{15}$ Pada pengertian ini, ada pemahaman yang tersirat bahwa upah ditetapkan salah satunya oleh peraturan perundang-undangan. Dalam hal peraturan perundang-undangan menetapkan upah, maka yang dimaksud adalah 'upah minimum', sebagaimana tercantum di dalam Pasal 89 UU No. 13 Tahun 2003. Landasan hukum tentang upah minimum diantaranya Peraturan Menteri Tenaga Kerja dan Transmigrasi Nomor 7 Tahun 2013 tentang Upah Minimum, Peraturan Menteri Tenaga Kerja dan Transmigrasi Nomor 13 Tahun 2012 tentang Komponen dan Pelaksanaan Tahapan Pencapaian Kebutuhan Hidup Layak, serta yang terbaru, Peraturan Pemerintah Nomor 78 Tahun 2015 tentang Pengupahan, yang menjadi regulasi yang mengatur teknis tentang upah mini- mum. Dalam ketentuan-ketentuan tersebut, mekanisme penetapan upah minimum oleh Gubernur, selalu melibatkan subyek atau lembaga lain, yakni pekerja dan pengusaha, yang dikerangkakan dalam lembaga tripartit (dewan pengupahan). Upah minimum ditetapkan dengan memperhatikan rekomendasi Dewan Pengupahan Provinsi dan/atau Bupati/Walikota.

Besarnya upah, mula-mula ditetapkan secara kontraktual antara pekerja/buruh dengan pengusaha. Pekerja/buruh memiliki posisi tawar yang sama dengan pengusaha untuk memulai suatu hubungan kerja, yang dilahirkan dari perjanjian kerja. Pada hakikatnya perjanjian kerja mengacu pada suatu persetujuan bahwa pihak kesatu, yaitu buruh mengikatkan diri untuk menyerahkan tenaganya kepada pihak lain, yaitu majikan dengan upah selama waktu tertentu. ${ }^{16}$ Perjanjian kerja tersebut merupakan hukum yang dilahirkan yang kemudian memiliki sifat ganda ${ }^{17}$, yakni perikatan yang didasarkan pada hubungan yang bersifat pribadi dan hubungan yang bersifat ekonomis. Perjanjian kerja menjadi kaidah otonom yang paling utama bagi pekerja/buruh dan pengusaha.

Sedangkan kebijakan upah minimum, termasuk penetapan upah minimum, merupakan kaidah heteronom dimana ada intervensi negara untuk memberikan perlindungan terhadap hak pekerja. Upah minimum itu

$15 \quad$ Pasal 1 Angka 30 UU No. 13 Tahun 2003.

Pasal 1601a Kitab Undang-Undang Hukum Perdata.

H.P. Rajagukguk, Peran Serta Pekerja Dalam Pengelolaan Perusahaan (Buku Obor 2002) 85. 
dibebani dua prinsip mendasar yang harus dipertimbangkan. Yakni, upah yang ditetapkan pemerintah merupakan upah yang layak, dan melibatkan mitra dalam penentuan kebijakan tingkat upah minimum. Sebagaimana dikutip:

In designing minimum wages policies, two key principles should be kept in mind. The first is to use the minimum wage in the manner it was intended, namely to provide a decent wage floor. The second principle is to involve social partners - not only in the design and monitoring of the minimum wage system, but also in the decision-making related to setting the level of the minimum wage. ${ }^{18}$

Bahwa kebijakan tentang upah minimum tetap harus memberikan peluang bagi tercapainya perwujudan kehidupan yang layak, yang dalam penyusunan kebijakan tersebut, pembuat kebijakan tidak boleh kemudian meninggalkan peran serta mitra atau adresaat yang nantinya terkena dampak langsung, baik dalam hal mendesain dan mengawal sistem pengupahan, maupun dalam hal menetapkan kebijakan tentang tingkat upah minimum.

Oleh ILO, ada dua hal utama yang berkaitan dengan kebijakan penetapan upah minimum. Pertama, "minimum wage policy should be seen as integral part of general economic and social policy. The positive and negative effects of minimum wage policy should be assessed carefully and counter balancing measures should be adopted, bearing in mind the need especially for employment promotion." Kedua, "minimum wage fixing should aim at providing a "safety net" and the criteria to be taken into account should include the cost of living, distribution of earnings, general economic conditions and level of development of the country, and comparable wages."19 Demikian bahwa kebijakan penetapan upah minimum, merupakan bagian dari kebijakan tentang makro ekonomi dan sosial, yang harus diterapkan dengan penuh pertimbangan akan pemenuhan kebutuhan dasar pekerja dan peningkatan kesejahteraannya. Upah minimum juga harus menjadi jaring pengaman, karena harus mampu mencukupi biaya hidup, penafkahan, kondisi ekonomi dan tingkat pertumbuhan ekonomi, serta perbandingan upah.

Pemerintah Indonesia, melalui UU No. 13 Tahun 2003, sudah mengatur bahwa kebutuhan hidup layak (KHL) menjadi yang faktor utama yang terang dan tegas dalam proses penetapan upah minimum. KHL ini disusun secara teknis melalui mekanisme yang diatur di dalam Permenakertrans No. 13 Tahun 2012 yang dilaksanakan oleh lembaga tripartit yakni Dewan Pengupahan yang tersusun dari kombinasi tiga unsur utama bidang ketenagakerjaan: pemerintah, pengusaha, dan pekerja/buruh. Dewan Pengupah-

\footnotetext{
18 ILO, Global Wage Report 2008/09 (International Labour Office in association with Academic Foundation 2008) 47.

19 APRLA, 'Minimum Wage Laws and Administration: The Widening Gap' (Proceedings and resource/ country papers of ILO/ARPLA Regional Seminar on Administration of Minimum Wages/Laws, Pattaya, Thailand, 12-16 February 1990) 6.
} 
an ini bertugas untuk mengadakan survei dan menyusun nilai KHL yang nantinya diperlukan dalam penetapan upah minimum (baik UMK maupun UMP) oleh Gubernur. KHL ini adalah pokok utama dalam penetapan upah minimum, karena menjadi dasar yang menentukan adanya kemampuan negara untuk menciptakan garis minimum upah yang memenuhi primary cost for living bagi pekerja.

Penetapan Upah Minimum oleh Gubernur berdasarkan KHL dan dengan memperhatikan produktivitas dan pertumbuhan ekonomi. Di samping itu Gubernur harus membahas secara simultan dan mempertimbangkan faktor-faktor sebagai berikut: (a) nilai KHL yang diperoleh dan ditetapkan dari hasil survei; (b) produktivitas makro yang merupakan hasil perbandingan antara jumlah Produk Domestik Regional Bruto (PDRB) dengan jumlah tenaga kerja pada periode yang sama; (c) pertumbuhan ekonomi merupakan pertumbuhan nilai PDRB; (d) kondisi pasar kerja merupakan perbandingan jumlah kesempatan kerja dengan jumlah pencari kerja di daerah tertentu pada periode yang sama; dan (e) kondisi usaha yang paling tidak mampu (margina) yang ditunjukkan oleh perkembangan keberadaan jumlah usaha marginal di daerah tertentu pada periode tertentu. Dalam penetapan Upah Minimum Gubernur memperhatikan saran dan pertimbangan Dewan Pengupahan Provinsi dan rekomendasi Bupati/ Walikota (Pasal 6 Permenakertrans No. 13 Tahun 2012).

Gubernur berwenang untuk: (a) menetapkan upah minimum provinsi, (b) dapat menetapkan upah minimum kabupaten/kota (UMK) atas rekomendasi Dewan Pengupahan Provinsi dan rekomendasi bupati/walikota, dan (c) dapat menetapkan upah minimum sektoral provinsi (UMSP) dan/atau Upah minimum sektoral kabupaten/ kota (UMSK) atas kesepakatan organisasi perusahaan dengan serikat pekerja/serikat buruh (SP/SB) di sektor yang bersangkutan. ${ }^{20}$ Sekalipun kewenangan untuk menetapkan besaran upah minimum merupakan 'milik' Gubernur, karena putusan finalnya ada padanya, akan tetapi rekomendasi dari Dewan Pengupahan dan Bupati/ Walikota wajib untuk diperhatikan. Alasan filosofinya adalah Dewan Pengupahan dan Bupati/Walikota memiliki pengetahuan dan wawasan mengenai perkembangan kehidupan masyarakat ketenagakerjaan atau pelaku produksi dalam penyusunan nilai KHL, potensi kerawanan masalah ketenagakerjaan (khususnya upah), maupun tentang perumusan perhitungan upah minimum. ${ }^{21}$ Keadaan yang demikian memperkaya informasi bagi Gubernur untuk mengambil

$20 \quad$ Lihat Pasal 6, Pasal 7, dan Pasal 11 Permenakertrans No. 7 Tahun 2013.

21 Sebelum berlakunya PP No. 78/2015 tentang Pengupahan, masing-masing daerah (provinsi dan kabupaten/kota) dapat merumuskan sendiri model perhitungan dalam rumusan rekomendasi/ usulan upah minimum, yang kemudian diajukan kepada Gubernur. Sedang sejak berlakunya PP tersebut, sudah diatur tentang rumus baku cara perhitungan upah minimum dari tahun ke tahun. 
keputusan berapa besaran upah minimum yang tepat.

Faktor pertimbangan utama adalah nilai KHL, dan berdasarkan PP No. 78 Tahun 2015 tentang Pengupahan, Presiden sudah menetapkan rumusan tentang cara perhitungan upah minimum. Gagasan utamanya yaitu upah minimum yang ditetapkan dapat mendukung pemenuhan kebutuhan hidup pekerja/buruh pada tingkat minimal. Hal ini berarti, nilai KHL menjadi lebih penting porsinya, karena menjadi rumusan awal rekomendasi Dewan Pengupahan dan Bupati/Walikota. Pentingnya KHL ini menjadi dasar bahwa kebutuhan pekerja/buruh yang lajang harus didukung tersedianya Penghasilan yang layak merupakan jumlah penerimaan atau pendapatan Pekerja/Buruh dari hasil pekerjaannya sehingga mampu memenuhi kebutuhan hidup Pekerja/Buruh dan keluarganya secara wajar (Pasal 4 PP No. 78 Tahun 2015).

\section{Upah Minimum:}

\section{Problematika Diskresi Gubernur}

Pierre Laliberté menyatakan bahwa ada hubungan kepentingan ekonomi dalam bisnis dengan upaya perlindungan kesejahteran pekerja/buruh dan keluarganya, sebagaimana dinyatakan bahwa:

At the policy level, the issue of the minimum wage remains deeply controversial as it introduces moral considerations as to what constitutes minimal and fair compensation in a given economy and the role of minimum wage in ensuring that people earn enough through their labour to afford to sustain themselves and their families. Yet this entry of "morality" in a discipline that prides that sees itself as scientific and positivistic is always bound to be contentious especially if it goes against the "law of gravity" of neoclassical economics: a rise in price (wages) must necessarily result in a drop in demand. ${ }^{22}$

Upah minimum menjadi penentu apakah pemerintah dalam membentuk kebijakan pengupahan tersebut, memiliki pertimbangan moral untuk memberikan porsi yang sama bagi perlindungan bagi kepentingan bisnis pada satu sisi, dan perlindungan kesejahteraan pekerja/buruh beserta keluarganya. Diskresi sebagai inisiatif pembentuk kebijakan, apalagi Gubernur lah yang diperintah untuk menetapkan upah minimum, mampu menerjemahkan maksud dan tujuan kesejahteraan dengan cara yang kreatif dan inovatif.

Menjawab pertanyaan diskresi yang bagaimana yang dapat dilakukan Gubernur dalam menetapkan upah minimum, perlu dikaji kondisi mendasar mekanisme penetapan upah minimum. Gubernur yang kewenangannya menetapkan upah, merupakan pejabat administrasi negara yang juga memiliki kewenangan untuk melakukan diskresi. Kebijakan penetapan upah minimum ini ada pada kewenangan Gubernur, yakni berdasarkan Pasal 41 ayat (1) Peraturan Pemerintah (PP) Nomor 78

$22 \quad$ Pierre Laliberté, 'Social Justice and Growth: The Role of the Minimum Wage' (2012) 4 International Journal of Labour Research 7, 8. 
Tahun 2015 tentang Pengupahan ${ }^{23}$ yang menyatakan bahwa upah minimum merupakan jaring pengaman (safety net), upah bulanan terendah yang terdiri atas: (a) upah pokok tanpa tunjangan, dan (b) upah pokok termasuk tunjangan tetap. Tentang kesepakatan upah antara pekerja dengan pengusaha, negara memiliki kepentingan dalam menjaga agar pekerja/buruh tidak menjadi pihak yang terciderai hakhaknya. Sebagaimana konsep tujuan bernegara, yakni keadilan sosial, maka pada upaya untuk mendudukkan pekerja/buruh berada pada posisi tawar yang sama dengan pengusaha, maka pemerintah menetapkan upah minimum.

Perlu diingat yang berkaitan dengan upah minimum, adalah bahwa "minimum" tentu ditetapkan bukan oleh karyawan atau perwakilan karyawan. Logikanya, jika karyawan yang menentukan besarnya kebutuhannya per bulan, maka yang dipakai adalah "upah maksimum" bukan "upah minimum". Jelas bahwa ketentuan upah minimum pasti bukan oleh karyawan tetapi oleh oknum-oknum yang tentu hanya berhenti dengan memikirkan soal upah minimum, namun tidak pernah mengalami kondisi hidup dengan standar upah minimum. ${ }^{24}$ Mekanisme penetapan pengupahan, pekerja/buruh hanya bisa mengajukan usulan atau berkontribusi dalam perumusan penghitungan upah minimum, melalui lembaga tripartit, Dewan Pengupahan. Pekerja/ buruh diwakili oleh organisasi pekerja (serikat pekerja/serikat buruh) bersama dengan pengusaha yang diwakili oleh Asosiasi Pengusaha Indonesia (Apindo) dan pemerintah melalui wakilnya dari instansi yang membidangi ketenagakerjaan.

Ada pertanggungjawaban moral yang membebani pengambil kebijakan tentang upah minimum, yakni pemilik kewenangan untuk menetapkan upah minimum: Gubernur. Pemilik kewenangan ini harus memperhatikan bahwa konsepsi keadilan sosial di bidang ketenagakerjaan, salah satunya diwujudkan dengan penetapan upah minimum agar terjamin perlindungan akan hak atas upah yang layak (decent wage). Tentunya upah yang layak ini harus mempertemukan antara: besar penerimaan dan jumlah kebutuhan hidup yang layak bagi pekerja/buruh bersangkutan. Upah yang layak ini juga harus memperhatikan pula bagaimana tingkat kesejahteraan pekerja/buruh yang bersangkutan semata, tapi sampai kepada upaya mendorong keluarganya dapat turut meningkat kesejahteraannya.

${ }_{23} \quad$ PP No. 78 Tahun 2015 tentang Pengupahan merupakan peraturan yang menggantikan PP No. 8 Tahun 1981 tentang Perlindungan Upah. Ditetapkan dan berlaku sejak 23 Oktober 2015 yang menjadi perdebatan masyarakat kalangan pekerja/buruh dan pengusaha, dikarenakan pemberlakuan PP ini, mengakibatkan perubahan mekanisme perumusan upah minimum yang sebelumnya didasarkan pada model perumusan besarnya usulan upah minimum yang dibahas di mekanisme Dewan Pengupahan Kabupaten/Kota. Dengan PP No. 78 Tahun 2015, Dewan Pengupahan tidak diperkenankan membuat rumusan perhitungan sendiri, karena PP ini sudah menetapkan rumus perhitungan upah minimum.

24 L. Sinuor Yosephus, Loc. Cit. 
Diskresi dalam menetapkan upah minimum, menjadi titik tolak bagaimana Gubernur mempertajam alasanalasan substansial yang mendukung penetapan upah minimum yang tidak tunduk sepenuhnya pada peraturan perundang-undangan di bidang ketenagakerjaan. Perdebatan yang mengemuka dalam penetapan upah minimum, mula-mula ada pada pembahasan mengenai penyusunan dan perumusan nilai KHL. Pembahasan ini ditunjukkan dalam proses pelaksanaan survei, perhitungan, dan perumusan nilai KHL sebagai bahan usulan rekomendasi upah minimum. Dewan Pengupahan dibentuk dari tiga unsur: pekerja, pengusaha, dan pemerintah (yang kemudian melibatkan Badan Pusat Statistik). Baik pekerja/buruh dan pengusaha, memiliki kepentingan langsung dengan perkembangan hubungan kerja yang ada di wilayah/daerahnya masing-masing. Atau dalam arti yang sempit, kepentingan itu melekat pada kenyamanan bekerja dan berusaha di perusahaan tempat berlangsung hubungan kerja.

Hal prinsip yang dikelola tentang pelaksanaan upah adalah kepentingan keseimbangan antara kebutuhan pertumbuhan ekonomi pada sisi pengusaha dengan upaya perlindungan hak atas penghasilan yang layak pada sisi pekerja. Gubernur sebagai aparatur dituntut profesional dalam menjalankan perannya, bisa melakukan diskresi. Profesionalitas aparatur birokrasi dapat dikembangkan ketika mereka

25 Agus Dwiyanto, Op.Cit. 160. memiliki ruang yang memadai untuk mengambil diskresi. Hal ini dikarenakan kecenderungan birokrasi pemerintah pada masa kini bersifat rule-driven perlu untuk diperbaiki agar aparatur birokrasi memiliki kapasitas untuk merespons dinamika yang terjadi dalam lingkungannya secara kreatif dan responsive. Pengaturan diskresi diperlukan, karena akan menjaga keseimbangan antara hak untuk mengambil diskresi dan pertanggungjawabannya, termasuk dampaknya bagi masyarakat luas. ${ }^{25}$

Upah minimum dipandang sebagai wujud kebijakan yang rentan terhadap kepentingan politis tertentu. Upah minimum menentukan sampai sejauh mana kebijakan itu mendukung mekanisme pasar dan ekonomi, yang sekaligus menjamin upah yang layak untuk semua pekerja. Penetapan upah minimum itu juga harus mendorong suatu struktur upah yang adil secara keseluruhan, yang menjamin upah yang layak berhadap muka denga pilihan kebijakan pemerintah. Masalah yang akan dihadapi Gubernur dalam menetapkan upah minimum adalah dampak upah minimum terhadap ekonomi makro sebagai alat kebijakan, dan dampak sosialnya: It (minimum wage) isn't just a question of the least advantaged achieving a minimum wage, but macroeconomic question of what we as a political community ultimately wan the outcome of work to be. Though it is only one policy tool, whose application may well be limited, the minimum wage, along with other policy tools, doesn't speak to the larger question of political vision - the goals that we as a political community 
would like to achieve. And in this vein, it should also speak to the underlying purpose of public policy in a democratic polity. ${ }^{26}$

Tarik menarik kepentingan praktis antara kelayakan upah dan makro ekonomi ini, dipandang oleh ILO menjadi masalah klasik. ILO berpegang pada pengertian bahwa upah minimum adalah:

the minimum sum payable to a worker for work performed or services rendered, within a given period, whether calculated on the basis of time or output, which may not be reduced either by individual or collective agreement, which is guaranteed by law and which may be fixed in such a way as to cover the minimum needs of the worker and his or her family, in the light of national economic and social conditions. ${ }^{27}$

Upah minimum mengacu pada prestasi kerja, jangka waktu, cara perhitungannya (baik waktu atau hasil pekerjaan), yang kemudian tidak dapat direduksi (melalui kesepakatan secara individu atau kolektif). Upah ini harus dijamin dalam regulasi, dengan maksud untuk memberikan perlindungan atas upaya pemenuhan kebutuhan pekerja dan keluarganya.

Secara regulatif, upah minimum yang ditetapkan oleh Gubernur, harus tunduk pada ketentuan bahwa Gubernur:

a. menetapkan upah minimum dihitung dengan menggunakan formula perhitungan upah minimum, yaitu: $\mathrm{UMn}=\mathrm{UMt}+\{\mathrm{UMt} \mathrm{x}($ Inflasit $+\% \Delta \mathrm{PDBt})\} ;$

b. wajib menetapkan upah minimum provinsi, dan dalam hal ada penin- jauan KHL (per lima tahun), maka penetapan ini harus memperhatikan rekomendasi Dewan Pengupahan Provinsi (Pasal 45 PP No. 78 Tahun 2015);

c. dapat menetapkan upah minimum kabupaten/kota, dan besarnya harus lebih tinggi daripada upah minimum provinsi, dan dalam hal terdapat peninjauan KHL (per lima tahun), maka wajib memperhatikan rekomendasi Bupati/walikota dan saran Dewan Pengupahan Provinsi (Pasal 46 PP No. 78 Tahun 2015).

Ketentuan tersebut secara tegas memerintahkan kepada Gubernur untuk menetapkan upah minimum provinsi, sedang penetapan upah minimum kabupaten/kota merupakan kewenangan yang bisa dilakukan atau tidak dilakukan. KHL menjadi satusatunya ukuran tentang hidup yang layak pada pekerja, dan ditinjau per lima tahun sekali. Penetapan KHL sendiri menjadi domain Menteri yang membidangi ketenagakerjaan, serta dengan mempertimbangkan hasil kajian yang dilaksanakan oleh Dewan Pengupahan Nasional, yang menggunakan data dan informasi yang bersumber dari lembaga yang berwenang di bidang statistik. Upah minimum yang harus setara dengan nilai KHL, menghubungkan antara kepentingan penghasilan yang layak dengan kehidupan yang layak. Konvensi ILO No. 131 tahun 1970 dinyatakan bahwa:

26 Oren M. Levin-Waldman, The Case of the Minimum Wage: Competing Policy Models (State University of New York Press 2001) 2.

27 ILO, Minimum Wage System, International Labour Conference, 103rd Session (ILO Publication 2014$) 11$. 
The elements to be taken into consideration in determining the level of minimum wages shall, so far as possible and appropriate in relation to national practice and conditions, include (a) the needs of workers and their families, taking into account the general level of wages in the country, the cost of living, social security benefits, and the relative living standards of other social groups; (b) economic factors, including the requirements of economic development, levels of productivity and the desirability of attaining and maintaining a high level of employment. ${ }^{28}$

Pemahaman yang perlu ditekankan dengan regulasi ini adalah bahwa upah minimum merupakan safety nett agar menjaga keberlangsung usaha dan menjaga daya beli masyarakat. Upah minimum sendiri diterapkan atau dikenakan kepada pekerja/buruh yang non pengalaman (masa 0-1 tahun), jabatan terendah di perusahaan, dan bagi pekerja yang berstatus lajang. Layak dipertimbangkan pada masa lalu, sebelum adanya PP No.78 Tahun 2015 tentang Pengupahan, mekanisme penetapan upah minimum selalu diwarnai dengan politisasi, tekanan dan aspek lainnya yang menyebabkan rendahnya kepastian hukum dan kepastian berusaha. Masing-masing unsur yang menjadi pilar ketenagakerjaan, baik unsur pengusaha maupun unsur pekerja/buruh memiliki kepentingan yang besar dan krusial dalam mekanisme penetapan upah selama ini sehingga hampir selalu terjadi konflik horizontal. Melalui PP No. 78 Tahun 2015 pemerintah bermaksud menyediakan aturan yang lebih jelas dan mampu untuk menjaga keberlangsungan usaha dan keberlangsungan tenaga kerja, dengan tujuan mengakomodir asas prediktabilitas dan keberlangsungan, serta kepastian hukum dan usaha.

Lebih lanjut, sebagai peraturan teknisnya, baik PP No. 78 Tahun 2015 dan Permenakertrans No. 7 Tahun 2013, Gubernur wajib menetapkan Upah Minimum Provinsi. Upah ini harus mempertimbangkan nilai KHL, dengan kata lain harus diarahkan untuk pencapaian nilai KHL. Namun, ketentuan mengatur bahwa ada peluang bagi Gubernur untuk dapat menetapkan upah minimum di tidak setara nilai KHL. Hal ini sangat mungkin dilakukan oleh Gubernur bilamana dalam memberikan rekomendasi, Dewan Pengupahan Provinsi dan Bupati/Walikota mengajukan:

(a) rekomendasi upah minimum provinsi oleh Dewan Pengupahan disepakati (semua unsur ketenagakerjaan) di bawah atau lebih dari nilai KHL sesuai hasil survei yang dilakukan secara periodik;

(b) rekomendasi upah minimum kabupaten/kota oleh Bupati/Walikota berdasarkan kesepakatan dalam pembahasan perumusan usulan upah minimum, Dewan Pengupahan Kabupaten/Kota nilai usulan upah minimum lebih rendah atau lebih tinggi daripada nilai KHL.

28 Hansjörg Herr \& Milka Kazandziska, Principles of Minimum Wage Policy - Economics, Institutions and Recommendations, Working Paper No. 11 (Global Labour University 2011) 7. 
Menilik diskresi sebagai freies ermessen yang berarti bahwa sebagian kekuasaan yang dipegang oleh lembaga/ badan pembentuk undang-undang dipindahkan ke dalam tangan pemerintah/administrasi negara, sebagai badan eksekutif. Dalam hal ini badan eksekutif sebagai administratif negara tidak boleh menolak untuk memberikan pelayanan kepada masyarakat dengan alasan hukumnya tidak ada ataupun hukumnya ada tetapi tidak jelas, sepanjang hal tersebut masih menjadi kewenangannya. ${ }^{29}$ Jelas-jelas diatur di dalam PP maupun Permenakertrans, Gubernur wajib menetapkan upah minimum, yang didasarkan pada nilai KHL, akan tetapi Gubernur justru memutuskan upah minimum tidak setara dengan nilai KHL, yang dianggap 'menciderai' keadilan yang dimaksudkan dalam konsep pengupahan. Hal ini sejalan dengan pernyataan bahwa:

Therefore, to be justified at all, a government intervention had to be a last resort and implemented on a cautious basis. As a result, policy finds itself confronted with the following dilemma: insofar as an increase in the minimum wage increases the floor which may also serve as a reference point for other wage levels, and other wages in turn can expect to increase, the results will be beneficial to most and ultimately more people will be happy. ${ }^{30}$

Dengan menetapkan upah minimum melebihi atau kurang dari nilai KHL (yang disepakati) maka konsep kesejahteraan dan keadilan yang diaju- kan sebagai capaian, menjadi bias pengertian. Bila menetapkan upah minimum yang melebihi nilai KHL, maka pada satu sisi pekerja/buruh akan diuntungkan karena kesejahteraan mereka dapat bertambah. Perlu ditinjau bahwa upah minimum berlaku bagi pekerja dengan masa kerja 0-1 tahun, jabatan terendah, dan lajang. Secara bersamaan maka pekerja yang tergolong unskilled labor mendapatkan upah berlebih yang justru akan membahayakan ekonomi perusahaan. Hal ini terjadi karena kemudian status ekonomi komunitas masyarakat meningkat, standar menjadi lebih tinggi. Namun di sisi lain, upah minimum yang tinggi pengusaha akan berusaha untuk dapat meningkatkan skill pekerja/buruh yang tergolong unskilled labor tersebut, dengan mendorong mengikuti training, meraih pendidikan yang lebih tinggi, sehingga keterampilan dan keahliannya akan meningkat. Dinyatakan bahwa:

If the issue is education and training, raising the minimum wage could provide an incentive for employers to provide the type of on-the-job training that will effectively raise the productivity of lowskilled workers and make them higher skilled. Legislation aimed at increasing the minimum wage should offers policymakers an opportunity to approach this issue with a fresh perspective instead rehearsing old shopworn arguments. ${ }^{31}$

Gubernur harus mengambil keputusan yang dapat diterima kalangan pengusaha dan kalangan pekerja/buruh

\footnotetext{
29 Arfab Faiz Muhlizi, 'Reformulasi Diskresi dalam Penataan Hukum Administrasi' (2012) 1 Jurnal Rechtsvinding 93, 103.

30 Oren M. Levin-Waldman, Op.Cit. 17.

$31 \quad$ Ibid.12.
} 
terkait penetapan upah minimum. Upah minimum yang tinggi akan membahayakan dunia usaha, dan upah minimum yang rendah (terutama di bawah nilai KHL) akan mendegradasi kepentingan kesejahteraan pekerja/ buruh. Dengan inisiatif Gubernur, maka penetapan upah minimum diharapkan agar masalah keadilan tanpa hukum dapat dilaksanakan dengan keinginan atau instuisi seseorang yang di dalam mengambil keputusan mempunyai ruang lingkup diskresi yang luas serta tidak ada keterikatan pada perangkat aturan umum tertentu. Bentuk keadilan dapat bersifat judisial sedang yang kedua mempunyai ciri administratif. Pound menganjurkan agar kedua bentuk keadilan terdapat pada sistem hukum. ${ }^{32}$ Gubernur berada pada ruang dilema ketika akan menetapkan upah minimum jika tidak sesuai dengan rekomendasi upah minimum yang disampaikan oleh Dewan Pengupahan Provinsi dan Bupati/ Walikota.

Ketegangan antara hukum dan diskresi penegak hukum mencerminkan hak-hak asasi dan hak-hak pemilikan (property rights) antara perlindungan terhadap kemerdekaan individu dengan perlindungan terhadap tata hukum yang berlaku. Pertentangan hukum dan ketertiban akan selalu timbul, sehingga diskresi dalam kaitannya dengan asas nulla poena, diharapkan diskresi akan menghendaki hukum daripada ketertiban. ${ }^{33}$ Contohnya Gubernur Jawa Tengah tidak melaksanakan kewajiban untuk menetapkan 'upah minimum provinsi' (UMP) yang menjadi kewajiban dalam Pasal 45 ayat (1) PP No. 78 Tahun 2015 dan Pasal 6 ayat (1) Permenakertrans No. 7 Tahun 2013. Gubernur Jawa Tengah pada tahun 2015 hanya menetapkan Upah Minimum Kabupaten/Kota (UMK) untuk tahun 2016, yang secara langsung mengesampingkan kewajibannya untuk menetapkan UMP. Dalam pandangan diskresi, maka keputusan Gubernur ini bisa mengindikasikan adanya kepentingan tertentu yang hendak dicapai. Gubernur dapat dianggap menyalahi perintah undang-undang, yang menyebabkan adanya perilaku administratif yang menepikan kewajiban yuridisnya sebagaimana diatur di dalam peraturan perundang-undangan. Namun ada alasan kemanfaatan yang lebih luas dan bisa diterima: tidak menetapkan upah minimum provinsi, karena dengan menetapkan upah minimum kabupaten/kota lebih menjaga agar tidak menjadi kesejahteraan pekerja/buruh yang homogen, dan sesuai dengan potensi pelaksanaan hubungan kerja di masing-masing daerah. Pertimbangan lain bahwa UMP merupakan UMK terendah, maka sekalipun tidak ditetapkan dalam produk hukum, secara tidak langsung ada ukuran paling minimal di suatu provinsi tentang upah minimum.

\footnotetext{
32 Pound dalam Tina Asmarawati, Sosiologi Hukum: Petasan Ditinjau dari Perspektif Hukum dan Kebudayaan (Deepublish 2014) 116.

$33 \quad$ Ibid. 103.
} 
Rekomendasi Dewan Pengupahan Provinsi dan Bupati/Walikota, yang pada prinsipnya disusun dengan melibatkan Dewan Pengupahan, menunjukkan landasan moral yang kuat bilamana upah minimum ditetapkan tidak setara dengan nilai KHL. Alasannya sederhana, dimana Dewan Pengupahan Provinsi atau Dewan Pengupahan Kabupaten/Kota, di dalamnya sudah terdiri dari unsur-unsur ketenagakerjaan (pemerintah, pekerja, dan pengusaha) melakukan penyusunan dan perumusan nilai KHL sebagai syarat utama untuk menetapkan upah minimum. Gubernur menempatkan rekomendasi ini sebagai tanggung jawab moral bahwa rasa keadilan dan kesejahteraan di-nilai-kan dalam bentuk nilai KHL, yang memberikan persepsi yang kurang lebih sama antara pekerja dengan pengusaha. Kesepakatan tentang nilai KHL menjadi kekuatan pertanggung jawaban Gubernur untuk bertindak diskresi, karena alasan kepentingan umum yang lebih luas:

Minimum wage policy supported by a strong social policy is an efficient mechanism against poverty and income erosion of the poorest households. Minimum wage is one of the instruments which can control wage dispersion and in this way reduce income inequality. It can also help to prevent a general decline in the level of nominal wages and deflationary developments. ${ }^{34}$

Dalam artian bahwa penetapan upah minimum oleh Gubernur, baik lebih rendah dari nilai KHL atau lebih tinggi dari nilai KHL, akan memberikan efek keseimbangan antara kesejahteraan buruh dengan kepentingan ekonomis perusahaan.

\section{PENUTUP}

Penetapan upah minimum oleh Gubernur merupakan bentuk intervensi pemerintah dalam hubungan kerja antara pekerja/buruh dengan pengusaha. Gubernur sebagai pejabat administrasi negara dalam menetapkan upah minimum, mewujudkan kepentingan tujuan welfare state yang berupaya mendorong tercapainya keadilan sosial di tempat kerja. Hal ini berarti, adil bagi pekerja/buruh untuk mendapatkan penghasilan yang layak bagi kemanusiaan, dan adil bagi pengusaha untuk mendapatkan kepastian akan kenyamanan melakukan kegiatan usaha.

Pengusaha dalam melaksanakan hubungan kerja, dilarang membayar upah yang nilainya berada di bawah upah minimum. Menetapkan upah minimum harus melibatkan nilai kebutuhan hidup layak (KHL) sebagai wujud kepastian kelayakan pemenuhan kebutuhan hidup pekerja/buruh. Penyusunan dan perumusan nilai KHL menjadi alat ukur bagi besar kecilnya upah minimum yang ditetapkan. Maka, peran pelaku produksi yakni pengusaha, pekerja, dan pemerintah, dalam penyusunan nilai KHL melalui survei, pengumpulan data, penyusunan, serta perumusannya, diwujudkan dalam kelembagaan Dewan Pengupahan Provinsi dan Dewan Pengupahan

\footnotetext{
34 Hansjörg Herr $\&$ Milka Kazandziska, Op.Cit. 1.
} 
Kabupaten/Kota. Untuk mendorong terciptanya rasa keadilan, maka Gubernur dalam menetapkan upah minimum, tunduk pada ketentuan UU No. 13 Tahun 2003, PP No. 78 Tahun 2015, Permenakertrans No. 13 Tahun 2012 dan Permenakertrans No. 7 Tahun 2013.

Gubernur memiliki pertimbangan moral yang lain, yang menempatkan kepentingan hubungan kerja yang mendukung harmonitas, kenyamanan bekerja dan kelangsungan berusaha. Gubernur dapat melakukan diskresi dalam rangka penetapan upah yang berkeadilan, dengan cara (a) menetapkan upah minimum kabupaten/kota saja dan tidak menetapkan upah minimum provinsi, (b) menetapkan upah minimum yang lebih rendah atau lebih tinggi dari nilai KHL, yang merupakan kesepakatan para pelaku produksi melalui mekanisme perumusan rekomendasi di Dewan Pengupahan; dan (c) menetapkan upah minimum yang setara atau sama dengan nilai KHL, mengabaikan rekomendasi Dewan Pengupahan dan/atau Bupati/Walikota yang mengajukan usulan upah minimum yang dianggap kurang memenuhi ekspektasi nilai KHL.

Alasan yang dapat diajukan dalam melakukan diskresi tersebut antara lain untuk mewujudkan tujuan keadilan sosial di bidang ketenagakerjaan, yang dirasa lebih tepat dilakukan, bilamana rekomendasi atau situasi hubungan industrial kurang bisa diterima atau tidak mencerminkan kesepemahaman akan upah yang layak. Diskresi tersebut dapat dimaksud- kan untuk mendorong tercapainya Pasal 27 ayat (2) UUD 1945 yang menyatakan bahwa tiap-tiap warga negara berhak atas pekerjaan dan penghidupan yang layak bagi kemanusiaan.

Diskresi penetapan upah minimum oleh Gubernur, merupakan pembuatan kebijakan upah minimum yang tidak menetapkan upah minimum provinsi dan hanya menetapkan upah minimum untuk kabupaten/kota, adalah pengambilan keputusan atau tindakan atas inisiatif sendiri, tidak terpaku pada ketentuan aturan atau undang-undang yang mengatur tentang pengupahan. Dalam pertimbangan melakukan diskresi ini, dikarenakan Gubernur dapat memandang kepentingan masyarakat pekerja/pengusaha dan pengusaha, memiliki kesepahaman tentang nilai kebutuhan hidup layak, yang lebih sesuai dengan daerahnya sendiri-sendiri. Alasan ini secara administratif dapat dipertanggungjawabkan karena mengantisipasi keadaan tertentu kepemerintahan, yakni intervensi terhadap perlindungan upah. Diskresi ini dapat diajukan sebagai upaya untuk memberikan perlindungan yang sama bagi pekerja/ buruh dengan pengusaha.

\section{DAFTAR BACAAN}

\section{Buku}

Asmarawati, Tina, Sosiologi Hukum: Petasan Ditinjau dari Perspektif Hukum dan Kebudayaan (Deepublish 2014). 
Basah, Sjachran. Eksistensi dan Tolok Ukur Peradilan Administrasi Negara di Indonesia. (Penerbit Alumni 1997).

Dwidjowijoto, Riant Nugroho, Kebijakan Publik untuk Negara-Negara Berkembang (PT. Elex Media Komputindo 2006).

Dwiyanto, Agus, Mengembalikan Kepercayaan Publik Melalui Reformasi Birokrasi (PT. Gramedia Pustaka Utama 2011).

Hadjon, Philipus M., Pengantar Hukum Administrasi Indonesia (Gajah Mada University Press 2001).

H.R., Ridwan, Hukum Administrasi Negara (Rajawali Press 2008).

ILO, Global Wage Report 2008/09 (International Labour Office in association with Academic Foundation 2008). , Minimum Wage System, International Labour Conference, 103rd Session (ILO Publication 2014).

Oren M. Levin-Waldman, The Case of the Minimum Wage: Competing Policy Models. (State University of New York Press 2001).

Mankiw, N. Gregory, Makroekonomi (Penerbit Erlangga 2006).

Nasution, Mirna, Politik Hukum dalam Sistem Ketatanegaraan Indonesia (Puspantara 2005).

Rahardjo, Satjipto, Hukum dan Perilaku: Hidup Baik adalah Dasar Hukum yang Baik (Penerbit Buku Kompas 2009).
Rajagukguk, H. P., Peran Serta Pekerja Dalam Pengelolaan Perusahaan (Buku Obor 2002).

Simorangkit, JCT. Kamus Hukum (Sinar Grafika 2008).

Yosephus, L. Sinuor, Etika Bisnis: Pendekatan Filsafat Moal terhadap Perilaku Pebisnis Kontemporer (Yayasan Pustaka Obor Indonesia 2010).

\section{Jurnal dan Kertas Kerja}

ARPLA, 'Minimum Wage Laws and Administration: The Widening Gap' (Proceedings and resource/country papers of ILO/ARPLA Regional Seminar on Administration of Minimum Wages/Laws, Pattaya, Thailand, 12-16 February 1990).

Herr, Hansjörg, \& Milka Kazandziska, 'Principles of Minimum Wage PolicyEconomics, Institutions and Recommendations' Working Paper (2011) 11 Global Labour University 2011.

Laliberté, Pierre, 'Social Justice and Growth: The Role of the Minimum Wage' (2012) 4 International Journal of Labour Research 7.

Mustamu, Julista, 'Diskresi \& Tanggung Jawab Administrasi Pemerintah' (2011) 17 Jurnal Sasi 1.

Muhlizi, Arfab Faiz, 'Reformulasi Diskresi dalam Penataan Hukum Administrasi' (2012) 1 Jurnal Rechtsvinding 93. 